\title{
ARGUMENTS USED FOR RESTRICTING INTERNATIONAL REAL PROPERTY TRANSACTIONS: CASE STUDY OF LATVIA
}

\author{
Jānis VIESTURS ${ }^{1}$, Armands AUZIN̦Š² ${ }^{2}$ Tatjana ŠTAUBE \\ ${ }^{1-3}$ Riga Technical University, Latvia \\ Corresponding author e-mail: janis.viesturs@rtu.lv
}

\begin{abstract}
There is a wide range of factors - political, economic, legal, etc., which either limit or promote international real property transactions. It is considered that real property alienation to foreigners enhances foreign investment and economic development, however, some countries tend to limit such transactions. The current research provides a scientific view to reveal the reasons why certain countries impose different kinds of restrictions on international real property transactions. The objectives of this publication are: 1) to find out and analyse the existing arguments and reasons for limiting international real property transactions; 2 ) to determine the number and volume of international real property transactions in Latvia; 3) to identify the main argumentation for the current step and significant decline of international real property transactions in Latvia. Empirical analysis based on the review of scientific publications, statistical and comparative analysis of real property transactions are the main methods employed for this research.
\end{abstract}

Keywords: International real property transactions, foreign real property ownership, real property ownership restrictions, temporary residence permit

\section{INTRODUCTION}

Openness to international investments is a strong indicator of the level of economic freedom of a nation. However, most countries have different kinds of restrictions on foreign investment including international real property transactions, which affect foreigners gaining real property in their possession ${ }^{1}$. Some of these restrictions have to do with suspicion, xenophobia, racial motivation, prejudice, lack of loyalty, as well as other protectionist motivations. Nowadays, there are nations which have no restrictions at all placed on international transactions ${ }^{2}$, however, at the same time, there are other nations

\footnotetext{
${ }^{1}$ International law prescribes in The Rio Declaration on Environment and Development (1992) that states have the sovereign right to exploit their own resources pursuant to their own environmental and developmental policies, and the responsibility to ensure that activities within their jurisdiction or control do not cause damage to the environment of other states or of areas beyond the limits of national jurisdiction. Therefore, states are free to regulate foreigners' land ownership within the particular state.

${ }^{2}$ For example, in England, Finland, France, Germany, Sweden and the Netherlands.
} 
(a minority of European states (Schmid et al., 2005)) which have varying levels of restrictions on such transactions. Hence, the issue of foreign real property ownership continues to be a hot topic in many nations (Hodgson et al., 1999).

Real property ownership or use rights by foreigners can be restricted or limited in many ways. Most often such restrictions are based on a particular historically developed national policy regarding real property ownership or use rights of the foreigners. Various policy objectives are achieved as a result of such restrictions, which in each case are determined within the pertinent historical, political and economic contexts (Hodgson et al., 1999). Each country uses direct or indirect restrictions, also known as "barriers", for foreigners to acquire real property or use rights using such terms as "restrict", "prohibit", "regulate" and "limit". In the current scientific publication, the term "restriction" is chosen and used by the authors to describe any activities or regulations, which lead to a diminishing number of the international real property transactions in a particular country.

The current scientific paper is a part of the ongoing research on the theme "The effects of the factors that influence international real property transactions on the economy of Latvia". Recent discussions regarding the regulation of the international investment activities, which mainly address the issue of real property, have become quite topical for Latvia (Viesturs \& Auzins, 2016). The main reasons are changes in the geopolitical situation and recovering from the consequences of the economic crisis of 2008-2009.

First, in this research the authors consider arguments why certain countries historically have imposed particular restrictions on international real property transactions. Secondly, they analyse recent dynamics in real property transaction statistics in Latvia involving international investors during the period when conditions on obtaining a temporary residence permit were tightened. Thirdly, the main argument used in Latvia to restrict international real property transactions in 2014 is identified.

This research consists of three main parts:

1) Scientific publication review. In this chapter, studying selected scientific publications the authors identified the arguments used to restrict real property ownership or use rights by foreigners with an aim to inductively establish "categories" (Mayring, 2000), i.e. to identify the arguments most frequently used by the scientists in terms of imposing restrictions on foreign real property ownership or use rights. Scientific publications were chosen from the internationally recognised scientific citation databases (Elsevier SCOPUS, Thomson Reuters Web of Science, EBSCO) according to the following parameters:

- the results were obtained in a determined area (countries and regions) by studying scientific publications, in which the authors share results of their research; the papers were specifically chosen considering the region of research and whether they address the countries characterised by different economic development levels: from East-Central Europe (Tesser, 2004; Wood, 2004; Burger, 2005; Gugushvili, 2016), 
worldwide investments from Europe (Antonelli et al., 2015), Africa (Cotula \& Vermeulen, 2009; Zoomers, 2013; German et al., 2013; Hailu et al., 2015), Central Asia (Daurova \& Esenkulova, 2007), Latin America (Florit \& Piedracueva, 2011; Borras et al., 2012; Perrone, 2013; Fairbain, 2015), North America (Bell \& Savage, 1980; Lazarus, 1987; Price, 1999; Grant, 2008; Tirres, 2013);

- scientific publications covered the following research areas: agricultural law (Wilson, 2012), comparative law (Hodgson et al., 1999), economics (Borras et al., 2012; Fuerst, et al., 2015; Karodia \& Soni, 2013), foreign direct investments (Vrountas, 1990), geopolitics (Wood, 2004), land use policy (Teklemariam et al., 2015; Mycoo, 2005; Antonelli et al., 2015), law (Tirres, 2004), legal history (Bell \& Savage, 1980; Price, 1999; Lazarus, 1987; Tirres, 2013), political science (Qin, 2015), therefore the research can be described as interdisciplinary;

- the publications chosen for this research cover a wide spectrum of arguments rather than focus on a single one.

2) International real property transactions and the number of first-time temporary residence permits in Latvia. In this chapter, the authors present results of the analysis based on the available official statistics on international real property transactions, as well as the dynamics of the data regarding the issued first-time temporary residence permits based on real property investment in Latvia. The timespan from 2010 to 2015 is a determined limitation to the research. The main reason for such limitation was the easing of rules on the issue of the first-time temporary residence permits, which was launched by the local government in 2010, the rules were revised and became more restricted in 2014.

3) Determining the current official argumentation to restrict international real property transactions in Latvia. In this chapter, the authors provide information based on the analysis of the official data on identification of the most significant issue as a measure to limit international real property transactions in Latvia in 2014.

The following methods were applied in the present research: statistical, historical, empirical, and comparative analysis, along with the analysis of primary and secondary sources. Review of the scientific publications was utilised to identify the arguments used to restrict real property ownership or use rights by foreigners.

\section{SCIENTIFIC PUBLICATION REVIEW}

In order to determine the arguments for restrictions regarding international real property ownership, it is insufficient to use overall categorization - political, economic, legal, etc., because these general characterizations are too broad. 
The authors have performed a more detailed study of the arguments, which are mentioned in scientific publications with regard to restricting land ownership by foreigners. As a result, this research approach has shown that the arguments can be grouped into the following twelve categories:

1) Threat to national security (Vrountas, 1990; Hodgson et al., 1999; Price, 1999; Wood, 2004; Daurova \& Esenkulova, 2007; Wilson, 2012; Fairbairn, 2015; Qin, 2015; Gugushvili, 2016). National security or military security is the reason used to restrict acquisition of land by foreigners in the border areas - "restricted zones"3. National security can be the basis for restrictions, for example, around military bases or in specific regions, but it can also be the reason for land ownership restrictions in the entire territory of a country, if the result would be partial loss of territorial power. Restrictions based on national security concerns can at times be explained by historically developed sentiment, which in practice can be easily circumvented. For example, in Brazil land acquisitions are restricted for foreign companies, but not for Brazilian companies controlled by foreigners ${ }^{4}$ (Fairbairn, 2015). Restrictions that exist to protect food security and to prevent economic domination can be included under the realm of national security (Hodgson et al., 1999). They can also be described as "protection of economic independence" or "protection of national resources (including national food security)".

2) Protection of national resources (including national food security) (Lazarus, 1987; Vrountas, 1990; Hodgson et al., 1999; German et al., 2013; Karodia \& Soni, 2013; Zoomers, 2013; Wilson, 2012; Fairbairn, 2015). Many authors emphasize that the argument "protection of valuable resources" is a strong enough basis to restrict land ownership by foreigners. Since the world food price crisis in 2007, it is common to speak about the "land grab" (Cotula \& Vermeulen, 2009; Borras et al., 2012; Edelman et al., 2013; Hailu et al., 2015) in Africa, Latin America, Asia and East Europe, when land transactions are characterised by a) foreignness, b) low transparency, c) low price, d) large-scale ownership or use right transactions, e) native population displacement, f) disregard of human rights, g) government involvement, h) replacement of native smallholder land tenure by large-scale entities, i) transactions most often associated with food or energy sectors. Any of these can be a substantial reason to justify foreign land ownership restrictions.

3) Threat to national sovereignty (Vrountas, 1990; Tesser, 2004; Florit \& Piedracueva, 2011; Perrone, 2013; Tirres, 2013; Fairbairn, 2015; Qin, 2015). The argument that land alienation to foreigners is a threat to the

\footnotetext{
3 For example, in the border areas of Bolivia, Honduras and Mexico. In some countries, international transactions in border areas are not prohibited, but special permission is required (in Greece).

${ }^{4}$ In Mexico, any foreigner willing to get around the restrictions can establish a Fideicomiso through a Mexican bank for a maximum term of 50 years, which can be automatically renewed for another 50-year period.
} 
national sovereignty is highly popular and has dominated the media and political debates and is promoted by national political parties, small and medium farmers, and the overall population (Perrone, 2013). This argumentation is deeply rooted in history. For example, in the history of England, land ownership by foreigners was a threat not only to the land tenure system, which stemmed from the ties of loyalty since the Middle Ages, but also to the kingdom itself (Tirres, 2013). This argumentation is largely explained by the fear that land alienation to foreigners can lead to the loss of national sovereignty when the foreigners "control" part of a country's land.

4) Anti-immigration policy (Lazarus, 1987; Hodgson et al., 1999; Price, 1999; Tirres, 2013; Zoomers, 2013; Qin, 2015; Gugushvili, 2016). Restriction of land ownership to immigrants is one of the anti-immigration policy tools. It was most often used during some historical periods, for example, in the United States to indirectly reduce immigration from the Far East. This argumentation is more pertinent again in the context of contemporary anti-immigrant rhetoric (Price, 1999).

5) National and cultural identity protection (Vrountas, 1990; Hodgson et al., 1999; Wood, 2004; Mycoo, 2005; Karodia \& Soni, 2013; Antonelli et al., 2015; Gugushvili, 2016). Land alienation to foreigners has long-term consequences and this issue is multi-dimensional comprising economic, political, social and spiritual aspects (Karodia \& Soni, 2013). One of these aspects is when land alienation results in the relocation of the native population, resulting not only in the loss of land, but also livelihood and identity loss (Huggins, 2010; Karodia \& Soni, 2013). Loss of land by the native population, including by means of land alienation to foreigners, tends to lead to loss of livelihood and loss of identity (Huggins, 2010; Gugushvili, 2016). Therefore, national and cultural identity can partially be associated with a particular place where customs and traditions are observed. Thus, for example, a loss of connection with land, particularly in the case of rural population, can result in the loss of their traditional environment when rural inhabitants move to cities. Restrictions on international land ownership can protect traditional village life and ensure that there is adequate supply of affordable housing for the native population (Hodgson et al., 1999).

6) Nationalistic sentiment (Lazarus, 1987; Vrountas, 1990; Hodgson et al., 1999; Tesser, 2004; Wood, 2004; Burger, 2005; Gugushvili, 2016). Land is a special asset, which is related to the territory of the country, it is an asset that affects food supply thus affecting nationalistic sentimental emotions (Vrountas, 1990). Historically, in most nations land was the object that was not alienable. Use of land was based on possession, not absolute ownership, which appeared on the world scene only in the early modern period. This is the source of feeling that the land is not alienable, in particular to foreigners. This point of view is especially strong in Eastern Europe, where during the Soviet occupation period land was 
owned by the state. After the collapse of the Soviet Union, strong nationalistic sentiment rose along with the conviction that the alienation of "Motherland" or "sale of the Motherland" is impermissible. This argumentation against land alienation to a foreigner on the whole can be described as "nationalistic sentiment".

7) Xenophobia and bias against foreigners (Bell \& Savage, 1980; Lazarus, 1987; Price, 1999; Wood, 2004; Burger, 2005; Tirres, 2013; Gugushvili, 2016). Xenophobia and bigotry is historically one of the most often used arguments against foreign land ownership. In American history, the "fear of aliens" among some citizens was a strong enough reason to prohibit foreign land ownership (Bell \& Savage, 1980; Tirres, 2013). In England, aliens were also regarded with extreme jealousy (Price, 1999). Such sentiments are mainly aimed at protecting domestic small farmers (Burger, 2005). This argument can be easily exaggerated, used for populist reasons and be especially harmful in relation to international investment.

8) Prevention of land speculation (Lazarus, 1987; Vrountas, 1990; Hodgson et al., 1999; Mycoo, 2005; Karodia \& Soni 2013; Zoomers, 2013). Historically, land speculation and absentee landlordism are among the fundamental reasons for land ownership restrictions to foreigners (Lazarus, 1987), especially in relation to the alienation of agricultural land. There has always been an opinion that foreigners, who desired to gain ownership of land, should be categorized as "investors", who add value to the land, and who in the majority of cases are seen as "worthy of support", and not "speculative businessmen" who are not worthy of support. For example, in Australia the real estate market is considered to be a national interest concern and Foreign Direct Investment policy aims at reducing speculative transactions because they provide no profit to Australia itself (Vrountas, 1990). National economic policy usually states that the interest land speculators take in agricultural land is not to use it for farming but rather to increase its price. This, as can be seen in Africa, has resulted in thousands of hectares of agricultural land lying fallow (Zoomers, 2013).

9) Prevention of land price increase (Lazarus, 1987; Vrountas, 1990; Tesser, 2004; Fairbairn, 2015). Argument against land price increase can be derived from land speculations. It is the argument of market protectionists, who hold the view that foreign demand should be excluded from the market. This is an especially strong argument used to protect the domestic farmland market. It is also described as fear of foreigner engagement in the local market, which, for example, was widely observed in Eastern European countries before they joined the EU.

10)Ethnic argument (Lazarus, 1987; Wood, 2004; Burger, 2005; Tirres, 2013; Grant, 2008). Ethnic argument has most often been used in some historical circumstances, for example in the United States in the nineteenth - early twentieth century, when "alien land laws" were one of the forms of antiAsian policy, which was significant in land ownership restrictions to some 
ethnic groups. Ethnic discrimination was also practised in the land reforms carried out after the Second World War in East Central Europe (Burger, 2005) and still has not disappeared (Wood, 2004).

11) Protection of native farmers (Lazarus, 1987; Burger, 2005; Cotula, 2013; Perrone, 2013; Tirres, 2013). Historically, this argument was utilised not only to protect native farmers, but also to discourage absentee-landlordism (Lazarus, 1987), especially by foreigners. Domestic (mostly small) farmers are protected also by reducing the speculative price increase. Protectionism of native farmers is associated with the following arguments: "threat to national and cultural identity", "nationalistic sentiment" and "fight against native population displacement".

12)Questionable allegiance (Lazarus, 1987; Price, 1999; Tirres, 2013; Qin, 2015). The statement that foreigners do not have allegiance to the country comes from feudalism when land ownership was directly connected to allegiance (Tirres, 2013). Under feudal land tenure it was presumed that land cannot be released from the control of the feudal lords to foreigners, who in the future could possibly become disloyal or even an enemy to the lord. Hence, allegiance was the most often used argument against foreign land ownership in the Middle Ages. Currently, it is also used as an argument by politicians. An opposing argument to this is that citizenship does not mean permanent loyalty, i.e. citizens, like aliens, may also be disloyal (Qin, 2015).

\section{INTERNATIONAL REAL PROPERTY TRANSACTIONS AND TEMPORARY RESIDENCE PERMITS IN LATVIA}

Worldwide from 2010 to 2014, Latvia was the least expensive country where a non-citizen could obtain a temporary residence permit, simply by purchasing real property for at least 71,139 EUR". This initiative often referred to as "Golden Visa program" proved to be the factor that had the most significant influence on real property transactions in Latvia in the recent decades.

The minimum purchase price requirement was increased to 250,000 EUR in the $3^{\text {rd }}$ quarter of 2014. After this change, the total sum of real property purchase deals (Fig. 2) and the number of international real property transactions in Latvia significantly decreased (Fig. 1).

\footnotetext{
5 in the areas outside of Riga Planning Region and outside of the nine largest cities of Latvia (Daugavpils, Jēkabpils, Jelgava, Jūrmala, Liepāja, Rēzekne, Rīga, Valmiera, Ventspils).
} 


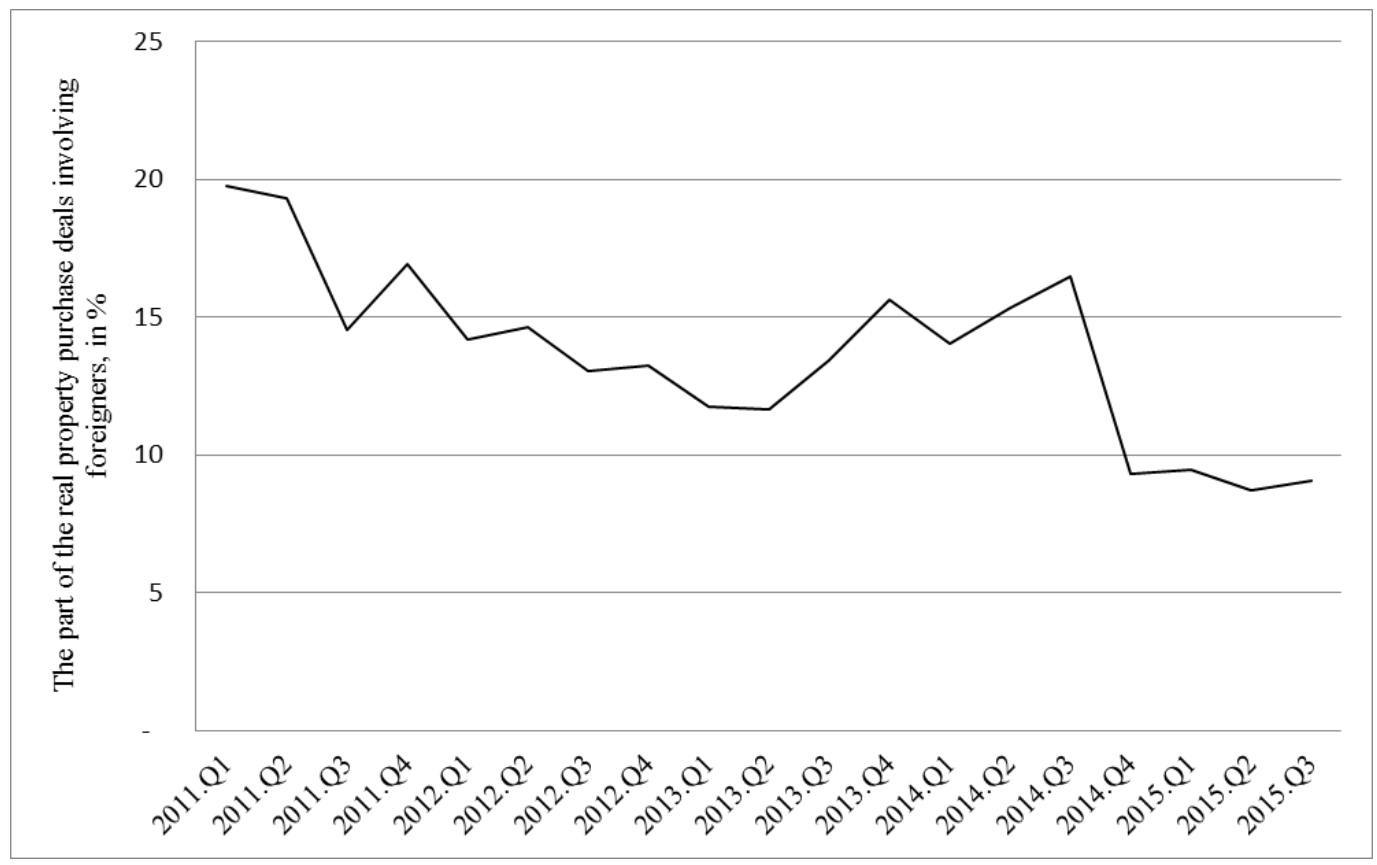

Fig. 1. Dynamics of the part of the total number of real property purchase deals in which foreigners were involved in Latvia from 2011 Q1 to 2015 Q3. Deals registered in the Land Registry of Latvia until 30.12.2015. (developed by the authors based on the data of the State Land Service of Latvia).

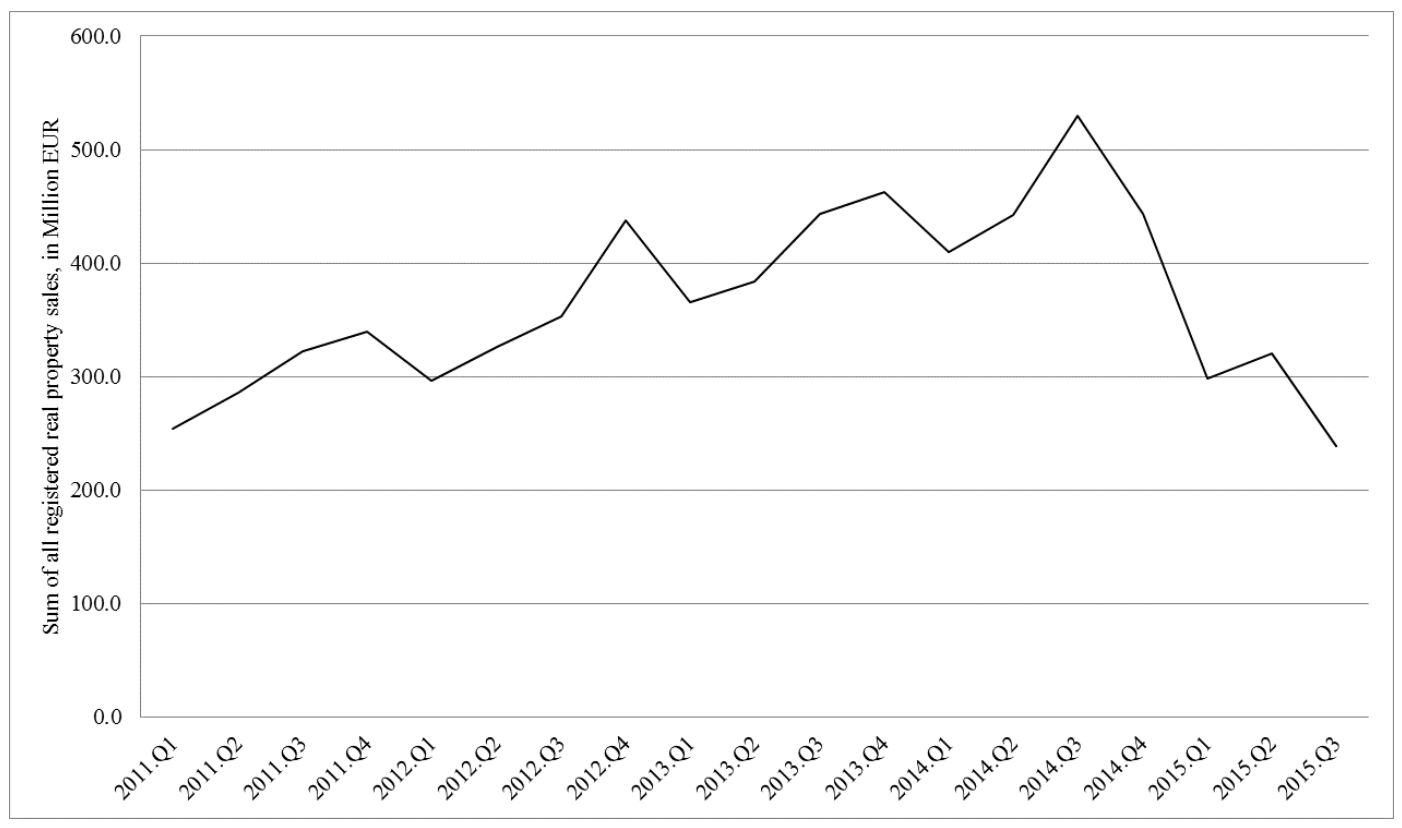

Fig. 2. Quarterly sum of all real property sales deals in Latvia from 2011 Q1 to 2015 Q3. Deals registered in the Land Registry of Latvia until 30.12.2015. (developed by the authors based on the data of the State Land Service of Latvia). 
In 2014, in Latvia the maximum number - 4,982 of first-time temporary residence permits issued to those who invested in real property (see Fig. 3) was reached. This was $47 \%$ of the total number of the first time temporary residence permits issued for the year. Starting with the third quarter of 2014, the number was decreasing. In 2016, the number of the first-time temporary permits issued in association with property investment comprised only $7 \%$ of all temporary residence permits issued.

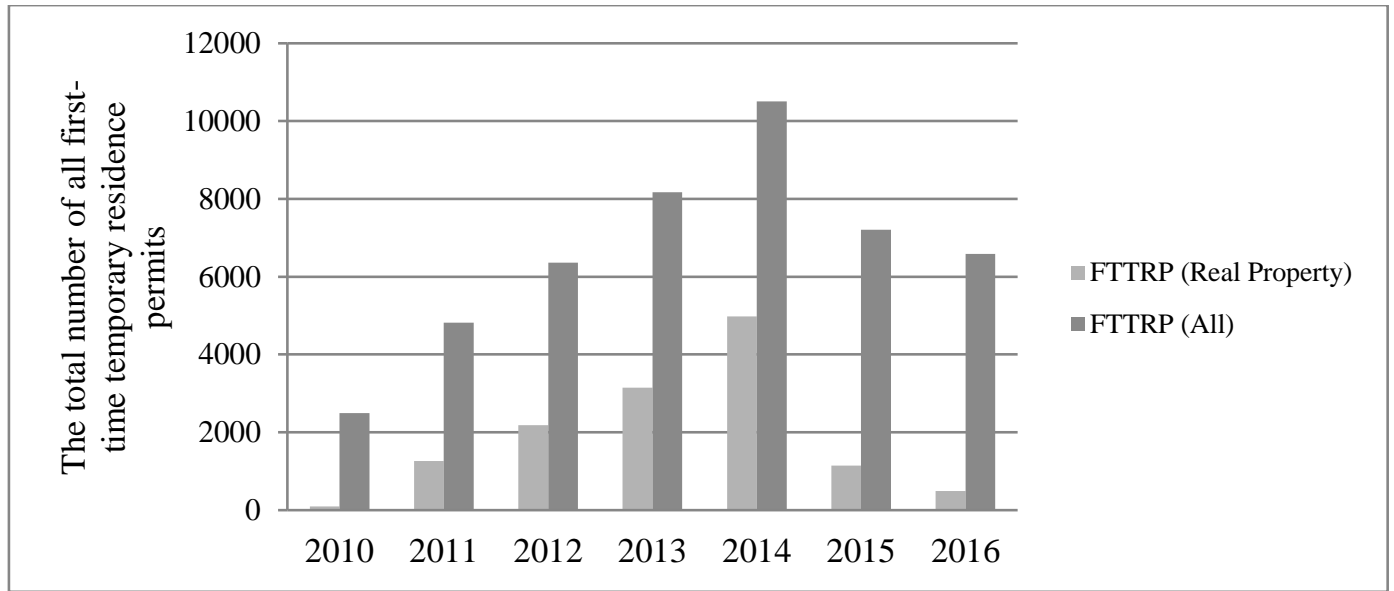

Fig. 3. The total number of all first-time temporary residence permits (FTTRP) and the number of FTTRP based on real property investment (FTTRP (Real Property)) issued in Latvia from 2010 to 2016. (developed by the authors based on the data of the Office of Citizenship and Migration Affairs of Latvia).

Seeing the substantial decrease in international real property transactions in the third quarter of 2014, it can be ascertained that this was the main factor influencing international real property transactions in Latvia during this time period.

\section{DETERMINING THE CURRENT ARGUMENTATION FOR THE RESTRICTION OF THE INTERNATIONAL REAL PROPERTY TRANSACTIONS IN LATVIA}

There were a few pro and contra arguments used regarding the national economy (Silina-Osmane et al., 2014; Vanags and Usenieks, 2015) to restrict the international real property transactions in Latvia, but due to changes in the geopolitical situation, the argument "threat to national security" dominated.

Official documentation has been worked out to initiate measures to restrict international real property transactions. According to the Annual Reports of the National Security Police of Latvia, in 2013 and 2014, the rapid growth of applications for residence permits increased the probability of previously identified potential national security risks. Namely, there was a risk that this procedure with the purpose to acquire the rights of residence in Latvia and the Schengen zone could be used by foreigners meeting the following criteria: 
1) related to foreign security and intelligence services or persons related thereto;

2) disloyal to Latvia and possibly involved in or supportive of activities against the interests of the country;

3) related to terrorist groups or organized crime;

4) engaged in financing activities aimed against the interests of the security of Latvia;

5) operating with money of unclear origin that flows into economic sectors of strategic significance.

After the minimum price requirement was increased to 250,000 EUR in the 3rd quarter of 2014 and strengthening of the capacity of the Security Police, in 2015 it was concluded by the Security Police of Latvia that the risk to the security interests of Latvia caused by the program of temporary residence permits decreased.

Repeated attempts in 2015 and 2016 were made to decrease the minimum requirement, however, the argument "a threat to national security" remained strong not allowing to implement this initiative. The Security Police always stated that the reduction of the volume of investments necessary for the receipt of residence permits may again increase the risk to the national security.

In the official report of the Ministry of the Interior ${ }^{6}$ it is stated that in the period from 2010 to 20161.154 billion euro, or $83 \%$ of the total sum of the received investments from foreigners to obtain temporary residence permit, was connected with real property transactions. From these statistics, the authors conclude that real property transactions are one of the most attractive activities for entering the local market.

There are ongoing discussions in Latvia whether or not it is in the interests of the national security to completely halt or suspend the opportunity to obtain the first-time temporary residence permit for the foreigners purchasing real property.

\section{FURTHER RESEARCH}

The authors plan to conduct a scientific survey among the stakeholders in the real property market in Latvia to find out the opinion of the real property market experts:

1) whether it is necessary to restrict foreign real property ownership;

2) what argumentation from the chapter on "Scientific Publication Review" is applicable to use to set restrictions and what goals are accomplished through these restrictions;

3) how restrictions to international real property transactions influence Latvia's economy.

\footnotetext{
${ }^{6}$ https://www.db.lv/ipasums/pedejos-sesos-gados-kopejie-ieguldijumi-kas-saistiti-ar-tuasanemsanu-veido-1-388-miljardus-eiro-455874
} 


\section{CONCLUSION}

The main conclusions of the study can be summarized as follows:

1. The review of scientific publications eliciting the arguments to restrict real property ownership by foreigners indicated that any of the identified detailed arguments can be a sufficient reason for the fundamental restriction of real property ownership or use rights for foreigners. That is a basic premise for further research.

2. The research on the identification of the analysed arguments in the case of Latvia resulted in the following key conclusions: the local government sets the policies based on the changes in the geopolitical situation. Since entering the EU and later struggling with the consequences of the economic crisis, it resulted in easing of conditions regarding foreign investments. However, currently, that has changed and the main argument used to restrict international real property transactions in 2014 was "a threat to national security".

3. In the case of Latvia, the authors observed and demonstrated how quickly and significantly the number of international real property transactions and the total sum of real property sales deals can be affected by the increase of the minimum price requirement for obtaining a temporary residence permit.

\section{REFERENCES}

Antonelli, M., Siciliano, G., Turvani M. E., \& Rulli, M. C. (2015). Global investments in agricultural land and the role of the EU: Drivers, scope and potential impacts. Land Use Policy, 47, 98-111. https://doi.org/10.1016/j.landusepol.2015.04.007

Bell, R. L., \& Savage, J. D. (1980). Our Land is Your Land: Ineffective State Restriction of Alien Land Ownership and the Need for Federal Legislation. J. Marshall L. Rev. 679, 13(3), 679-715. Retrieved from http://repository.jmls.edu/cgi/viewcontent.cgi?article=2395\&context=lawreview

Borras, S. M. Jr., Franco, J. C., Gómez, S., Kay, C., \& Spoor, M. (2012). Land grabbing in Latin America and the Caribbean. The Journal of Peasant Studies, 39(3-4), 845-872. https://doi.org/10.1080/03066150.2012.679931

Burger, A. (2006). Why is the issue of land ownership still of major concern in East Central European (ECE) transitional countries and particularly in Hungary? Land Use Policy, 23(4), 571579. https://doi.org/10.1016/j.landusepol.2005.01.003

Cotula, L. (2013). The New Enclosures? Polanyi, International Investment Law and the Global Land Rush. Third World Quarterly, 34(9), 1605-1629. https://doi.org/10.1080/01436597.2013.843847

Cotula, L., \& Vermeulen, S. (2009). Deal or no deal: the outlook for agricultural land investment in Africa. International Affairs, 85(6), 1233-1247. https://doi.org/10.1111/j.1468-2346.2009.00859.x

Daurova, Y., \& Esenkulova, B. B. (2007). Restrictions on the Land Ownership Rights of Foreign Individuals in the Kyrgyz Republic. Academic Review of the American University in Central Asia, 2. https://doi.org/10.2139/ssrn.1832956

Edelman, M., Oya, C., \& Borras, S. M. Jr. (2013). Global Land Grabs: historical processes, theoretical and methodological implications and current trajectories. Third World Quarterly, 34(9), 1517-1531. https://doi.org/10.1080/01436597.2013.850190

Fairbairn, M. (2015). Foreignization, Financialization and Land Grab Regulation. Journal of Agrarian Change, 15(4), 581-591. https://doi.org/10.1111/joac.12112 
Florit, P., \& Piedracueva, M. (2011). Extranjerización de la tierra: una caracterización. XXVIII Congreso ALAS, Recife, Brasil, en los días 6-11 de setiembre de 2011. Retrieved from https://www.academia.edu/1859981/Extranjerizaci\%C3\%B3n_de_la_tierra_una_caracterizaci\%C $3 \% \mathrm{~B} 3 \mathrm{n}$

Fuerst, F., Milcheva, S., \& Baum, A. (2015). Cross-Border Capital Flows into Real Estate. Real Estate Finance (Aspen Publishers Inc.). 31(3), 103-122. Retrieved from http://eds.b.ebscohost.com.resursi.rtu.lv/eds/pdfviewer/pdfviewer?vid=2\&sid=d8675fd9-aef5437f-9882-304ee3f85fb0\%40sessionmgr111\&hid=119

German, L., Schoneveld, G., \& Mwangi, E. (2013). Contemporary Processes of Large-Scale Land Acquisition in Sub-Saharan Africa: Legal Deficiency or Elite Capture of the Rule of Law? World Development, 48, 1-18. https://doi.org/10.1016/j.worlddev.2013.03.006

Grant, N. (2008). White Supremacy and the Alien Land Laws of Washington State. Seattle Civil Rights \& Labor History Project. Retrieved from http://depts.washington.edu/civilr/alien_land_laws.htm

Gugushvili, A. (2016). "Money can't buy me land": Foreign land ownership regime and public opinion in a transition society. Land Use Policy, 55, 142-153. https://doi.org/10.1016/j.landusepol.2016.03.032

Hailu, Y., Adelaja, A., Akaeze, H., \& Hanson, S. (2015). Explaining International Land Transactions in Africa. In Banking, Finance, and Accounting: Concepts, Methodologies, Tools, and Applications, 797-817. Hershey, PA: IGI Global. https://doi.org/10.4018/978-1-4666-6268-1.ch043

Hodgson, S., Cullinan, C., \& Campbell, K. (1999). Land Ownership and Foreigners: A Comparative Analysis of Regulatory Approaches to the Acquisition and Use of Land by Foreigners. FAO Legal Papers Online. Retrieved from http://www.fao.org/3/a-bb039e.pdf

Huggins, C. D. (2010). Land, Power and Identity roots of violent conflict in eastern DRC. Understanding conflict. Building Peace. Technical Report. International Alert 2010. Retrieved from https://www.researchgate.net/publication/275524756_Land_Power_and_Identity_roots_of_ violent_conflict_in_eastern_DRC

Karodia, A. M., \& Soni, P. (2013). African Land Tenure and Foreign Land Ownership: Threat or Opportunity? International Journal of Economics \& Business Studies, 3, (2), 3-20. Retrieved from http://eds.a.ebscohost.com.resursi.rtu.lv/eds/pdfviewer/pdfviewer?vid=13\&sid=e5635c1e2bcd-4fc1-9028-aa6530877dfa\%40sessionmgr4002\&hid=4202

Latvian Security Police. (2013). Annual Report. Retrieved from http://www.dp.gov.lv/en/

Latvian Security Police. (2014). Annual Report. Retrieved from http://www.dp.gov.lv/en/

Lazarus, M. L. (1987). An Historical Analysis of Alien Land Law: Washington Territory and State. University of Puget Sound Law Review, 12:197. Retrieved from http://digitalcommons.law.seattleu.edu/cgi/viewcontent.cgi?article=1286\&context=sulr

Mayring, P. (2000). Qualitative Content Analysis. Qualitative Social Research. 1(2), Art. 20. Retrieved from http://www.qualitative-research.net/index.php/fqs/article/view/1089/2385

Mycoo, M. (2005). Minimising foreign control of land in an era of globalisation prospects for St. Lucia. Land Use Policy, 22(4), 345-357. https://doi.org/10.1016/j.landusepol.2004.06.003

Perrone, N. M. (2013). Restrictions to Foreign Acquisitions of Agricultural Land in Argentina and Brazil. Globalizations, 10(1), 205-209. https://doi.org/10.1080/14747731.2013.760946

Price, P. J. (1999). Alien Land Restrictions in the American Common Law: Exploring the Relative Autonomy Paradigm. The American Journal of Legal History, 43(2), 152-208. https://doi.org/10.2307/846284

Rio Declaration on Environment and Development. (1992). The United Nations Conference on Environment and Development. Rio de Janeiro from 3 to 14 June 1992. Retrieved from http://www.unep.org/documents.multilingual/default.asp?documentid=78\&articleid=1163

Qin, X. (2015). A Political Study on Foreign Ownership of Land: Theoretical Challenges and Justifications. Manchester Journal of International Economic Law, 12(2), 195-211. Retrieved from http://www-scopus-com.resursi.rtu.lv/record/display.uri?eid=2-s2.0-84944387097\&origin= resultslist\&sort=plf 
Schmid, C. U., Hertel, C., \& Wicke, H. (2005). Real Property Law and Procedure in the European Union. General Report. Final Version. European University Institute (EUI) Florence/European Private Law Forum Deutsches Notarinstitut (DNotI) Würzburg. Retrieved from http://www.eui.eu/Documents/DepartmentsCentres/Law/ResearchTeaching/ResearchThemes/Eur opeanPrivateLaw/RealPropertyProject/GeneralReport.pdf

Siliņa-Osmane, I., Ieviņa, I., Briede, I. (2014). Trešo valstu pilsoṇu uzņemšana uzṇēmējdarbības nolūkos Latvijā. European Migration Network. Retrieved from: http://www.emn.lv/?p=1724

Teklemariam, D., Azadi, H., Nyssen, J., Haile, M., \& Witlox, F. (2015). Transnational land deals: Towards an inclusive land governance framework. Land Use Policy, 42, 781-789. https://doi.org/10.1016/j.landusepol.2014.09.021

Tesser, L. M. (2004). East-central Europe's new security concern: foreign landownership. Communist Post-Communist Studies, 37(2), 213-239, https://doi.org/10.1016/j.postcomstud.2004.03.006

Tirres, A. B. (2013). Ownership Without Citizenship: The Creation of Noncitizen Property Rights. Michigan Journal of Race \& Law, 19(1), 1-52. Retrieved from http://repository.law.umich.edu/cgi/viewcontent.cgi?article $=1000 \&$ context=mjrl

Vanags, J., Usenieks, D. (2015). Terminētās uzturēšanās atlauju ietekme uz nekustamo preču tirgu un tautsaimniecību: izvērtēšanas metodikas konceptuāls ietvars. In 56th International Riga Technical University Conference "Scientific Conference on Economics and Entrepreneurship SCEE '2015”. Riga, Latvia, 14-17 October, 2015, 215-216. ISBN: 978-9934-8275-3-2

Viesturs, J., Auzins, A. (2016). International Real Estate Transaction in Latvia 2011-2015: Theoretical and Practical Aspects. In Proceedings of the 2016 International Conference "Economic Science for Rural Development", Latvia, Jelgava, 21-22 April, 2016. Jelgava: Latvia University of Agriculture, 2016, 291-299. Retrieved from http://www.esaf.llu.lv/getfile.php?id=1586

Vrountas, C. T. (1990). The Necessity and Effectiveness of Barriers to Foreign Direct Investment, B. C. Int'l \& Comp. L. Rev. 167, 13(1), 167-205. Retrieved from http://lawdigitalcommons.bc.edu/iclr/vol13/iss1/7

Wilson, G. (2012). Reforming Alien Agricultural Landownership Restrictions in Corporate Farming Law States: A Constitutional and Policy View From Iowa. Drake Journal of Agricultural Law. 17(3), 709-753. Retrieved from http://eds.b.ebscohost.com.resursi.rtu.lv/eds/pdfviewer/ pdfviewer?vid=3\&sid=c12822c7-99e8-4b92-8043-fcf9a2584c5c\%40sessionmgr106\&hid=126

Wood, S. (2004). A Common European Space? National Identity, Foreign Land Ownership and EU Enlargement: The Polish and Czech Cases. Geopolitics, 9(3), 588-607. https://doi.org/10.1080/14650040490478666

Zoomers, A. (2013). A Critical Review of the Policy Debate on Large-Scale Land Acquisitions: Fighting the Symptoms or Killing the Heart? In S. Evers, C. Seagle \& F. Krijtenburg (Eds.), Africa for Sale?: Positioning the State, Land and Society in Foreign Large-scale Land Acquisitions in Africa. (pp. 55-77). Leiden: Brill. https://doi.org/10.1163/9789004252646 004

\section{AUTHORS' SHORT BIOGRAPHIES}

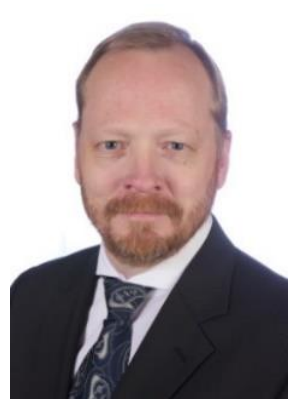

Jānis Viesturs, Mg. oec., is an Assistant Researcher of the Faculty of Engineering Economics and Management, Riga Technical University (Latvia). Jānis Viesturs has more than 20 years of experience in real property management, development, transactions and due diligence process. He is lecturing the course "International Real Property Transactions". Since 2015 he has participated in scientific conferences, congresses and workshops. His research interests cover real property definition, international and national real property transactions, different real property registration systems, real property due diligence process and real property management. He is a PhD student at RTU.

ORCID iD: http://orcid.org/0000-0002-0267-1858 


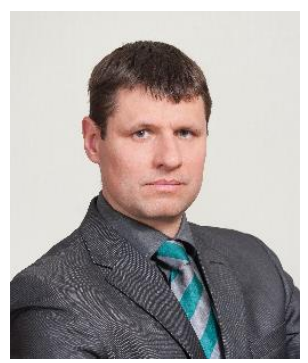

Armands Auzin̄š is an Associate Professor of the Faculty of Engineering Economics and Management, Riga Technical University (Latvia). He holds the degree of Doctor of Economic Sciences. He is a scientific expert in management and economic sciences of the Latvian Council of Science. He is a participant of the European Academy of Land Use and Development and a board member of the Latvian Association of Land Surveyors (FIG member). He has more than 15 years of consulting experience in land use management. His main research topic is the methodology development for evaluation of land use efficiency in land management. He is lecturing on land management and has a number of publications in journals and conference proceedings. He has participated in international research projects. His research interests include land use management, institutional and real estate economics, and evaluation techniques.

ORCID iD: http://orcid.org/0000-0002-4341-5201

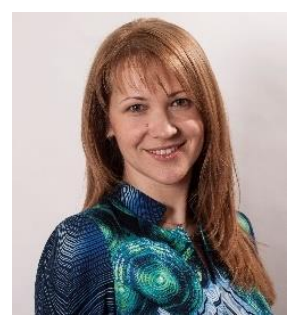

Tatjana Štaube, Dr.oec., Researcher and Assistant Professor at Riga Technical University. Research interests: commercial real estate, feasibility studies, financial analysis, market research, spatial economic allocation, strategic business development planning, sustainable development. Within over 15 years of professional experience she worked with Colliers International, Rimi Latvia, and the Ministry of Environmental Protection and Regional Development of Latvia, participated in 5 international scientific and practical projects. Tatjana Štaube is an author and co-author of around 40 scientific publications. She is an active participant in scientific conferences, congresses and workshops. Dr. Staube is an awardee of the RTU Senate's scholarship, Student Exchange Programmes in Norway and Finland and FIABCI Scholarship. Mrs. Staube is an expert in Management and Economic Sciences at the Latvian Council of Science.

ORCID iD: http://orcid.org/0000-0002-7874-0872 